\title{
scripted
}

Volume 16, Issue 1, August 2019

\section{Book review: Research Handbook on Intellectual Property and Creative Industries}

Abbe Brown and Charlotte Waelde (eds.)

Cheltenham: Edward Elgar, 2018. 401 pages. ISBN 9781786431165. £170.

Reviewed by Jake Campbell*

(c) (1) $\circledast \Theta$

(C) 2019 Jake Campbell

Licensed under a Creative Commons Attribution-NonCommercial-

NoDerivatives 4.0 International (CC BY-NC-ND 4.0) license

DOI: $10.2966 /$ scrip.160119.73

* Commercial, Rights \& Business Affairs Executive (Lawyer), BBC, Manchester, United Kingdom, jake.campbell@bbc.co.uk 
Elgar Law's Research Handbook on Intellectual Property and Creative Industries is the latest addition to its growing Research Handbook series and provides a whistlestop tour of the interaction between intellectual property (" $\left.\mathrm{IP}^{\prime \prime}\right)$ and the "Creative Industries". For the purposes of this book, the term "Creative Industries" encompasses a wide range of content including advertising, architecture, fashion, software, film, music, publishing and broadcasting (p. 79). Although films, music and video games are part of the Creative Industries, this Research Handbook does not cover these types of work in great detail and interested readers should consult Richardson and Ricketson's book in the same series for more detail. ${ }^{1}$

The Research Handbook will be of most interest to readers following developments in the United Kingdom, given that it focuses on its legal framework for IP protection. That said, the case studies included in the book also cover a diverse range of other countries, such as Romania, India and Japan.

The book is split into six parts, starting with "Setting the Scene" and ending with some thoughts on the future direction of the Creative Industries. Part I outlines the various IP rights relevant to the Creative Industries and explains them in a clear and logical way. The level of explanation means that this part will be of most use to non-IP practitioners or laypersons. In particular, those working in the Creative Industries may tend to think that copyright is the only relevant IP right, and this section is a good reminder (or informer) to readers that there may be other valuable rights to consider, exploit or enforce, such as patents and trade marks.

Part II, "National and Regional Perspectives", outlines some of the issues currently faced by the Creative Industries in the UK, Africa, Europe, India and Japan. However, these chapters are too brief to be any more than an introduction

1 Megan Richardson and Sam Ricketson (eds.), Research Handbook on Intellectual Property in Media and Entertainment (Cheltenham: Edward Elgar, 2017). 
to subjects such as the protection of TV formats, the lack of exceptions and limitations to copyright in Africa and the latest copyright reforms in the EU. It should be noted that by covering "Africa" or "Europe" in such few pages, there is a risk in overgeneralisation which limits their probative value.

Part III considers the "sharing economy" and IP enforcement. Guadamuz examines the rise of Creative Commons and other open licences for copyrighted works and notes the difficulty in adopting such a model for registered rights. Rizk's case study on sharing music in Egypt is a useful example of how creative businesses wishing to expand into less developed countries will need to appreciate that their existing business models such as online payment systems are unsuitable in cash economies. In Chapters 13 and 14, Cornwell and Brown outline the IP enforcement framework in the United Kingdom and the existing empirical studies of IP litigation. Cornwell demonstrates that as the data-driven economy grows, this will be a growth area for future empirical research, which is currently significantly behind studies in the United States.

Part IV contains a series of case studies on the relationship between IP and subject matters such as visual arts, traditional clothing and dance. The main themes of this section are embodied in Kheria's chapter comparing the IP needs of illustrators with those of other visual artists: (i) that copyright law is not a suitable one-size-fits-all framework for all types authors; (ii) creators need to be more vocal in terms of the kind of protection they want; and (iii) more research needs to be carried out to better understand their priorities. These issues are reinforced in the chapters by Sabiescu and Collins which highlight the gaps in IP protection for traditional crafts, traditional knowledge and folklore. Keshet's chapter on copyright in museums is particularly enlightening, giving real-life examples of the pervasiveness of copyright law, and how arguably ill-suited it is to the modern era because it can obstruct humanitarian and non-commercial purposes. 
Part V considers the various justifications for IP protection. Stapleton informs readers that copyright has its roots in censorship and privilege, and that the modern-day justification for copyright (protection of investment) has been undermined by the marginal cost in digital reproduction. He also notes the increased polarisation in the copyright debate (as seen in Reda's chapter in Part II) and the "campaign rhetoric" used by different interest groups following Lawrence Lessig's Creative Commons initiative. Moving on from theory, Mandel provides results of a survey on the public's understanding of IP rights, noting that there is a "plagiarism fallacy" - i.e. that the public equate "infringement" as merely being a lack of attribution, when its legal meaning is far different.

The final part of the Research Handbook, "Foresighting", is a mixture of issues that face the Creative Industries. Searle's discussion on the relationship between economics and IP is particularly important. It explains the difficulty in measuring the contribution of IP to the economy because of its intangible nature and a lot of information is confidential to the relevant business. Searle notes that although there has been "[...] scepticism to the value of attaching numbers to otherwise ephemeral goods [...]" (p. 355), governments are now placing more weight on economic data to drive their IP policymaking. This fits well with Handke's discussion in Chapter 5 on the economic justifications for IP protection.

The Research Handbook is a good introduction to various IP-related problems faced by the Creative Industries. Three themes are clearly resonant throughout:

- The ongoing balancing act between the rights of content owners and consumers:

Interwoven throughout the Research Handbook is evidence that the traditional justification for IP rights is often divorced from reality and 
public opinion suggests that there is currently an imbalance between owners and consumers of content.

- Highlighting problematic areas of IP law for future research and where policymakers and interest groups in the Creative Industries could press for reforms:

It is a useful guide for these areas, as demonstrated in Handke's commentary in particular. He challenges existing economic justifications for copyright and encourages further research and statistical analysis to avoid "policy-making by gut feeling" (p. 60). Other chapters, such as those by Cornwell, Sabiescu and Collins, provide new angles for researchers to explore in the future.

- The ongoing challenges faced in the digital era:

Several chapters deal with this problem. The authors of Chapter 24 explain that existing business models that involve IP are under threat due to the "democratisation" of production, reproduction and distribution and low barriers to entry (p. 312). As Hartley notes in Chapter 28, the digital age has transformed everyone into a publisher and author, and the existing copyright framework is arguably no longer suitable. He is also critical of content owners' attempts to use copyright as a "consumer-micropayment harvesting tool" (p. 370).

The role and impact of IP is not purely a legal question. A particularly strong point of the Research Handbook is the various backgrounds of the contributors. This is welcomed and provides a broader perspective on IP rights for those working in the Creative Industries. Beyond the mix of legal scholars and practising lawyers, there are valuable contributions from non-legal scholars, economists, museum managers, politicians and civil servants. 